\section{IDENTIFYING \\ SHALLOW \\ SUBSURFACE \\ CHARACTERISTICS VIA COMPRESSIONAL TO SHEAR WAVES VELOCITY RATIO (VP/VS) FROM SEISMIC REFRACTION TOMOGRAPHY}

\author{
Muhammad Syukria*, Nordiana M. Muztazab, Nur Azwin Ismailb, Zul \\ Fadhlic, Rosli Saadb* \\ aDepartment of Physics, Faculty of Sciences, Syiah Kuala University, \\ Banda Aceh, Indonesia \\ bSchool of Physics, Universiti Sains Malaysia, 11800 Pulau Pinang, \\ Malaysia \\ cDepartment of Geophysics Engineering, Faculty of Engineering, \\ Syiah Kuala University, Banda Aceh, Indonesia
}

Article history

Received

10 May 2020

Received in revised form

15 October 2020

Accepted

4 November 2020

Published online

17 December 2020

*Corresponding author m.syukri@unsyiah.ac.id

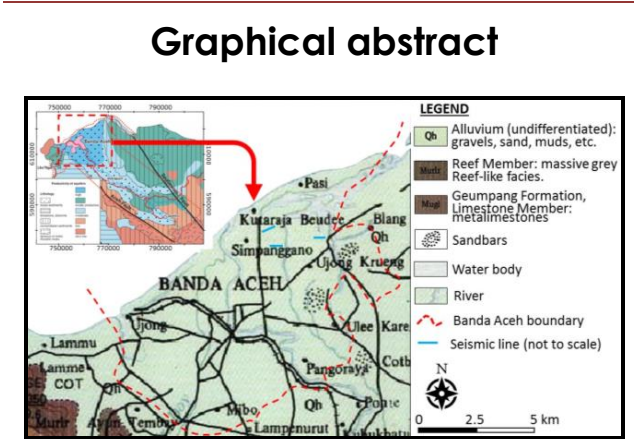

\begin{abstract}
This study was conducted in Banda Aceh district by utilizing seismic refraction Pand S-waves methods on three similar profile lines, with the aim to identify subsurface characteristic. The seismic data were acquired using ABEM TERRALOC MK8 system with $28 \mathrm{~Hz}$ vertical and $6 \mathrm{~Hz}$ horizontal geophones, and suitable seismic sources. Software used for processing to produce 2-D tomography sections and interpretations are IXRefract, Microsoft Excel, SeisOpt@2D v6.0 and Surfer 8 . The results show the study area comprises of four subsurface layers with strong to very strong relation between $V p$ and $V s\left(R^{2}\right.$ is $\left.>0.7509\right)$ for each layer. Ratio value of $\mathrm{Vp}$ and $\mathrm{Vs}$ ( Vp/Vs) for each layer (1st to 4th) was calculated to be 4.75 - 5.79; $6.50-8.89 ; 6.57-12.17$ and 6.08 - 8.21 respectively. This study concluded that the ground subsurface in Banda Aceh district is made up of water saturated unconsolidated sediments that was identified to be a mixture of clay and silt at depth up to $55 \mathrm{~m}$.
\end{abstract}

Keywords: Seismic refraction, velocity, ratio, tomography, coefficient of determination

\begin{abstract}
Abstrak
Kajian ini dijalankan di daerah Banda Aceh dengan menggunakan kaedah sismik pembiasan gelombang-P dan -S ke atas tiga garis profil yang sama, bertujuan untuk mengenal pasti ciri subpermukaan. Data sismik ini diperolehi menggunakan sistem ABEM TERRALOC MK8 bersama geofon menegak $28 \mathrm{~Hz}$ dan mendatar $6 \mathrm{~Hz}$, serta sumber sismik yang sesuai. Untuk menghasilkan keratan 2-D tomografik dan penafsiran, perisian digunakan adalah IXRefract, Microsoft Excel, SeisOpt@2D v6.0 dan Surfer 8. Keputusan menunjukkan kawasan kajian terdiri daripada empat lapisan subpermukaan dengan hubungan yang kuat dan sangat kuat antara $V p$ dan $V s\left(R^{2}\right.$ adalah $\left.>0.7509\right)$ bagi setiap lapisan. Nilai nisbah antara $V p$ dan Vs (Vp/Vs) bagi setiap lapisan (1 hingga 4) adalah 4.75 $5.79 ; 6.50-8.89 ; 6.57$ - 12.17 dan 6.08 - 8.21 masing-masing. Kesimpulan kajian menunjukkan subpermukaan tanah di daerah Banda Aceh terdiri daripada sedimen takterkonsolidasi bercampur lempung dan lumpur yang tepu air dengan kedalaman sehingga $55 \mathrm{~m}$.
\end{abstract}

Kata kunci: Sismik pembiasan, halaju, nisbah, tomografik, pekali penentuan

(c) 2021 Penerbit UTM Press. All rights reserved 


\subsection{INTRODUCTION}

Shallow seismic refraction processing procedures started with the Intercept Time method in the year 1930s [1]. The data acquisition and processing procedures have developed since 1980s to fulfil the engineering and environmental requirements $[1,2]$. Seismic refractions sometimes fail to resolve geological layers due to thin layer problem or insufficient velocity contrast [3].

The accessing of surface waves for shallow application including Spectral Analysis of Surface Waves (SASW) [4] and Multichannel Analysis of Surface Waves (MASW) [5, 6, 7, 8] provide great contributions to the engineering, environmental and archaeology applications $[3,9,10,11,12,13,14,15$, $16,17,18,19]$

Velocity ratio of compressional wave to shear wave (Vp/Vs) is widely and effectively used to investigate engineering site and seismic wave propagation in porous media including sea-floor sediments, groundwater and hydrocarbon bearing formations. Characteristics such as porosity, lithology, mineralogy, consolidation and fluid saturation contribute to the elastic moduli variations. Clay content and water saturation are factors that contribute to the changes in Vp/Vs ratio. Thus, the $\mathrm{Vp} / \mathrm{Vs}$ ratio can be used to model and evaluate lithological properties and petrophysical parameters of sediments and rocks $[20,21,22,23,24,25,26,27]$. The $\mathrm{Vp} / \mathrm{Vs}$ are also used to identify fluid saturation for porous media, and the influence of water saturation and clay content $[28,29,30,31,32,33,34,35]$. Table 1 shows the research outcome using $\mathrm{Vp} / \mathrm{Vs}$ ratio.

This article aims to study the $\mathrm{Vp} / \mathrm{Vs}$ ratio for shallow subsurface in Banda Aceh district (Pasi, Kutaraja Beudee, Simpanggano, Ujong Krueng, Blang Krueng, Tiibang and Syiah Kuala) which dominated and overlaid by undifferentiated alluvium such as gravels, sand, muds, etc. [36]. The study outcome is expected to provide the $\mathrm{Vp} / \mathrm{Vs}$ ratio values in shallow subsurface by using seismic refraction $\mathrm{P}$ - and S-waves methods.

Table 1 Study outcome by researchers on $\mathrm{Vp} / \mathrm{Vs}$ ratio for sediments and rocks

\begin{tabular}{|c|c|}
\hline Authors & Outcome \\
\hline Pickett, 1960; 1963 & $\begin{array}{l}\text { The } V p / V s \text { values; } 1.65-1.75 \text { for sandstones, } 1.75-1.85 \text { for } \\
\text { dolomites and } 1.85-1.95 \text { for limestone. }\end{array}$ \\
\hline $\begin{array}{l}\text { Benzing, } 1978 \text {; } \\
\text { Benzing et al., 1983; } \\
\text { Hamilton, 1979 }\end{array}$ & $\begin{array}{l}\text { Presence of mud or shale in carbonates and sandstones } \\
\text { causes an increase in } \mathrm{Vp} / \mathrm{Vs} \text { up to } 13-46 \text { for sea floor } \\
\text { muds. }\end{array}$ \\
\hline Salem, 1993 & $\begin{array}{l}\text { Shales (clays) rich zones show greater values of } \mathrm{Vp} / \mathrm{Vs} \\
\text { than zones of lesser amounts of shales or zones that are } \\
\text { composed of other kinds of lithology, such as } \\
\text { sandstones, carbonates or conglomerates. }\end{array}$ \\
\hline $\begin{array}{l}\text { Gardner and Harris, } \\
1968\end{array}$ & $\begin{array}{l}\text { The Vp/Vs values less than } 2 \text { for unconsolidtaed } \\
\text { sediments saturated with gas or oil and more than } 2 \text { for } \\
\text { unconsolidated sediments saturated with oil or water. }\end{array}$ \\
\hline Gregory, 1977 & $\begin{array}{l}\mathrm{Vp} / \mathrm{Vs} \text { values of } \sim 1.5 \text { for gas-saturated sandstone, } 1.62- \\
2.02 \text { for oil saturated reservoirs and } 1.63-2.18 \text { for brine- } \\
\text { saturated reservoirs. }\end{array}$ \\
\hline Tatham, 1982 & $\begin{array}{l}\text { Vp/Vs values: 1.78-2.4, corresponds to highly } \\
\text { hetereogenous shaly sandstone reservoirs saturated with } \\
\text { mutiphase fluids (oil, gas and brine). }\end{array}$ \\
\hline $\begin{array}{l}\text { Eastwood and } \\
\text { Castagna, } 1983\end{array}$ & $\begin{array}{l}\text { Vp/Vs values: } 1.8 \text { for quartz-rich, }>5 \text { for loose, water- } \\
\text { saturated sediments. }\end{array}$ \\
\hline Stuempel at al., & $\mathrm{Vp} / \mathrm{Vs}$ values of up to 9, corresponds to water-saturared \\
\hline
\end{tabular}

\begin{tabular}{|l|l|}
\hline Authors & Outcome \\
\hline $\begin{array}{l}1984 ; \text { Meissner et } \\
\text { al., } 1985\end{array}$ & sediments having clays. \\
\hline $\begin{array}{l}\text { Castagna et al., } \\
1985\end{array}$ & $\begin{array}{l}\text { Vp/Vs values of 1.45 for quartz spheres, velocity ratio } \\
\text { decreases with increasing degree of sphericity of grains } \\
\text { (or increase with increasing degree of grain angularity). }\end{array}$ \\
\hline Tatham, 1985 & $\begin{array}{l}\text { Silts and sands with similar grain shapes show greater } \\
\text { values of Vp/Vs than sands, eventhough both silts and } \\
\text { sands have the same porosity. }\end{array}$ \\
\hline $\begin{array}{l}\text { Juneja and Endait, } \\
2017\end{array}$ & Vp/Vs values for basalt is 1.89 based on lab experiments \\
\hline
\end{tabular}

\subsection{GENERAL GEOLOGY}

The study was conducted in the northern part of Banda Aceh district (Figure 1). Generally, Banda Aceh district is dominated and overlaid by undifferentiated alluvium which consists of gravels, sands, muds, etc. This region is in the Krueng Aceh valley zone which is flanked by Tertiary and Quaternary volcanic mountains. On the other hand, sandbars are rarely found in this district. The Reef Member with massive grey Reef-like facies can be found in the western part of this district. A mountain ridge of limestone is laying from southwest to southeast part of this district, known to be the Geumpang Formation, with Limestone Member of metalimestones $[36,37]$.

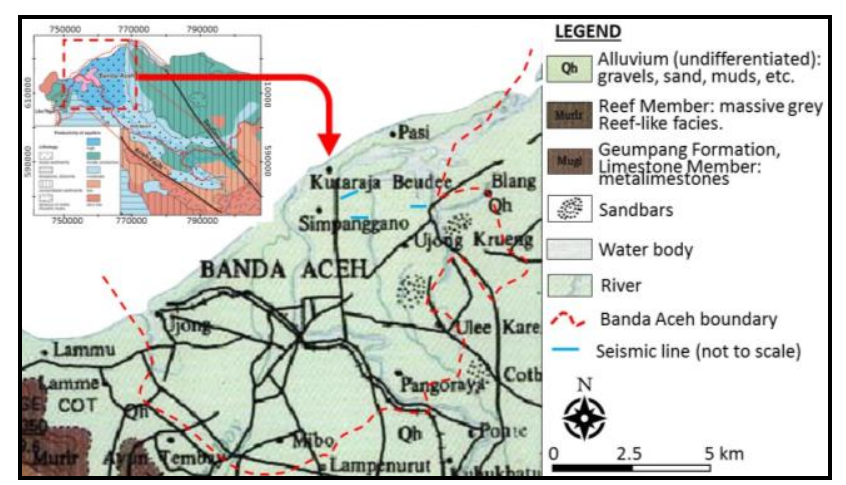

Figure 1 Geology map of Banda Aceh, Sumatra [36, 38, 39, 40]

\subsection{METHODOLOGY}

Three seismic refraction survey profile lines (Table 2) were conducted to cover the area of Pasi, Kutaraja Beudee, Simpanggano, Ujong Krueng, Blang Krueng, Tiibang and Syiah Kuala which represent the soil subsurface of the study area (Figure 2).

Table 2 Coordinate of the seismic refraction profile lines at Banda Aceh study area

\begin{tabular}{|l|l|l|l|}
\hline Profile name & Distance $(\mathbf{m})$ & Latitude $\left(^{\circ} \mathbf{N}\right)$ & Longitude $\left(^{\circ} \mathbf{E}\right)$ \\
\hline S1 & 0 & 5.590133 & 95.331412 \\
\hline & 115 & 5.590187 & 95.332447 \\
\hline S2 & 0 & 5.581190 & 95.336462 \\
\hline & 115 & 5.581344 & 95.337497 \\
\hline S3 & 0 & 5.584987 & 95.348244 \\
\hline & 115 & 5.585015 & 95.349320 \\
\hline
\end{tabular}




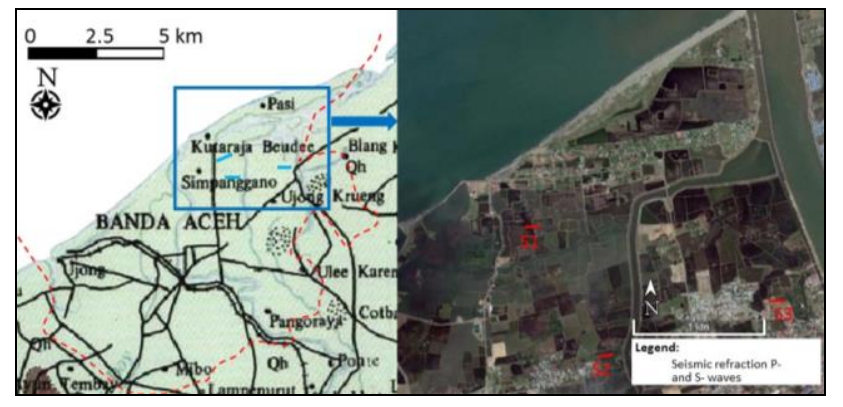

Figure 2 Seismic refraction profile lines of $\mathrm{P}$ - and S-waves at study area $[36,41]$

The seismic refraction P-wave was conducted on the three profile lines using 24 channel seismograph ABEM TERRALOC MK8 system which was connected to $28 \mathrm{~Hz}$ vertical geophones using a pair of seismic cables. The geophones were placed in a straight line with the geophone spikes planted on the ground surface with a constant $5 \mathrm{~m}$ geophone spacing. A series of vertical strikes on a metal plate using a $5 \mathrm{~kg}$ sledgehammer produces seismic P-waves, which will then be detected by the geophones and recorded/saved by the seismograph (Figure 3). The location of the strike (shot) points were arranged in such a way that they are laid along the seismic profile line (Table 3).

Seismic refraction S-wave was conducted on the same three profile lines using the same seismograph system. The $28 \mathrm{~Hz}$ vertical geophones were replaced with $6 \mathrm{~Hz}$ horizontal geophones. The geophones were placed in a straight line on the ground surface with constant geophone spacing of $5 \mathrm{~m}$ with the consideration of the geophone vibration axis is perpendicular to the profile line. A wooden plank was placed under the vehicle front or back tyres in order to have its weight providing good friction contact with ground surface. The wooden plank was strike at the end of both sides to generate shear wave (Figure 3). The location of the strike (shot) points were arranged in such a way that they lay along the seismic profile line (Table 4).

Table 3 Shot point location for P-wave seismic refraction

\begin{tabular}{|l|l|l|}
\hline Profile name & Length $(\mathbf{m})$ & Shot points refer to 0 $\mathbf{m}$ as geophone $1(\mathbf{m})$ \\
\hline S1 & 115 & $-61,-40,-20,2.5,27.5,57.5,87.5,112.5,135,155,175$ \\
\hline S2 & 115 & $-45,-30,-15,2.5,27.5,57.5,87.5,112.5,130,145,160$ \\
\hline S3 & 115 & $-38,-15,2.5,27.5,57.5,87.5,112.5,130,145,160$ \\
\hline
\end{tabular}

Table 4 Shot point location for S-wave seismic refraction

\begin{tabular}{|l|l|l|}
\hline Profile name & Length $(\mathbf{m})$ & Shot points refer to $\mathbf{0} \mathbf{m}$ as geophone $\mathbf{1}(\mathbf{m})$ \\
\hline S1 & 115 & $-30,-20,-10,2.5,27.5,57.5,87.5,112.5,125,135,145$ \\
\hline S2 & 115 & $-30,-20,-10,2.5,27.5,57.5,87.5,112.5,125,135,145$ \\
\hline S3 & 115 & $-30,-20,-10,2.5,27.5,57.5,87.5,112.5,125,135,145$ \\
\hline
\end{tabular}

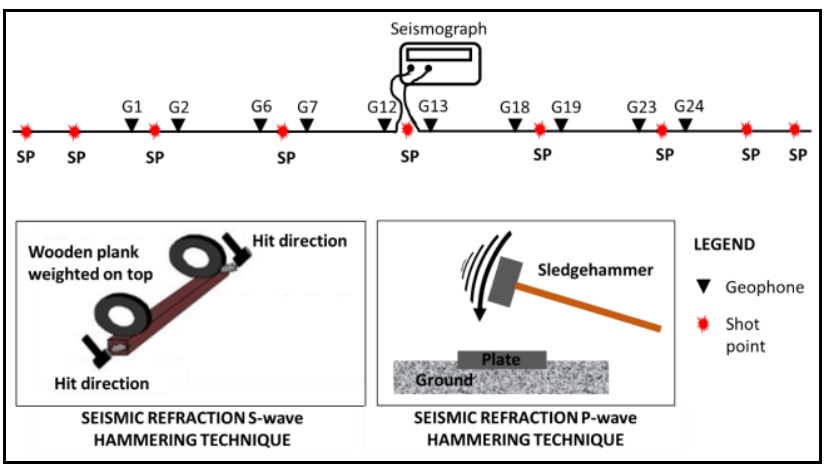

Figure 3 Seismic refraction layout and hammering technique for $\mathrm{P}$ - and S-wave $[42,43]$

The data (P-and S-waves) collected and saved in the seismograph were transferred into a computer for processing and interpretations following the flow chart shown in Figure 4 using several software (IXRefract, Microsoft Excel, SeisOpt@2D v6.0 and Surfer 8$)$. The direct current (DC) effect in the data was removed for better signal to noise ratio (S/N) quality. For the poor $\mathrm{S} / \mathrm{N}$ ratio, further processing steps were applied which include band pass/ low pass/ high pass to improve the ratio. The acceptable $\mathrm{S} / \mathrm{N}$ ratio data are saved as ${ }^{*} . \mathrm{sg} 2$ format for further processing using SeisOpt@2D v6.0 software to produce 2-D tomography section of subsurface for interpretation using Surfer 8 software.

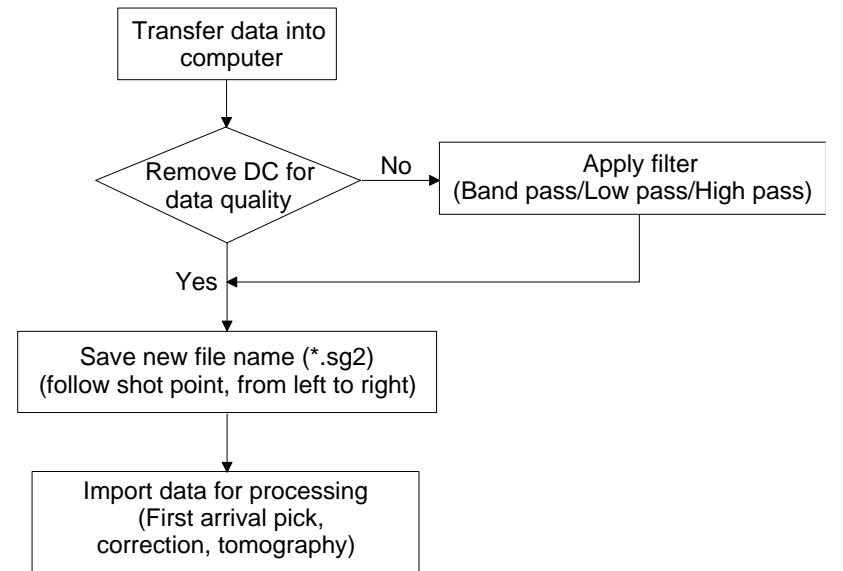

Figure 4 Seismic refraction P- and S-waves flow chart

\subsection{RESULTS AND ANALYSES}

Figure 5 shows an example of the seismic data with acceptable $\mathrm{S} / \mathrm{N}$ ratio including first arrival pick for the $\mathrm{P}$ - and S-waves. The first arrival times (refer to appropriate shot point) are plotted against geophone distance for validation of the picking of the first arrival time for profile lines $\$ 1-\$ 3$ respectively (Figure 6-8). 


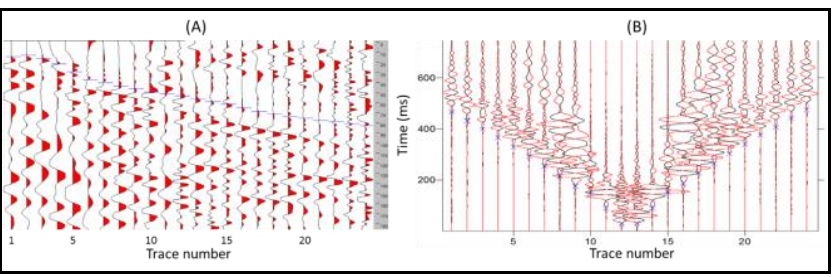

Figure 5 Seismic data with first arrival pick; (a) P-wave, and (b) S-wave
(A)

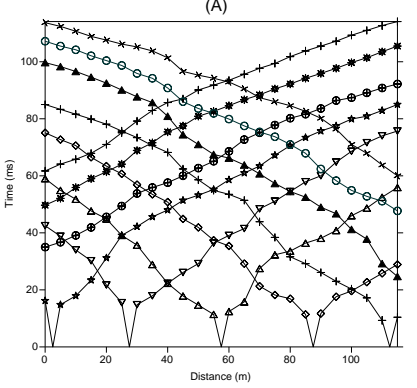

(B)

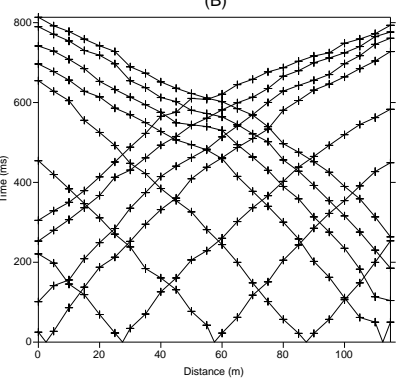

Figure 6 First arrival time vs distance graph for profile line S1; (a) P-wave, and (b) S-wave
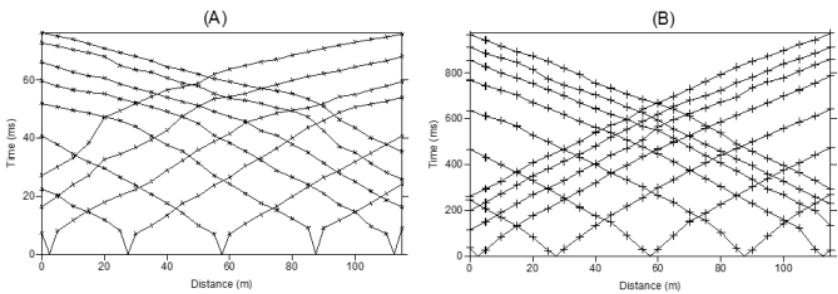

Figure 7 First arrival time vs distance graph for profile line S2; (a) P-wave, and (b) S-wave

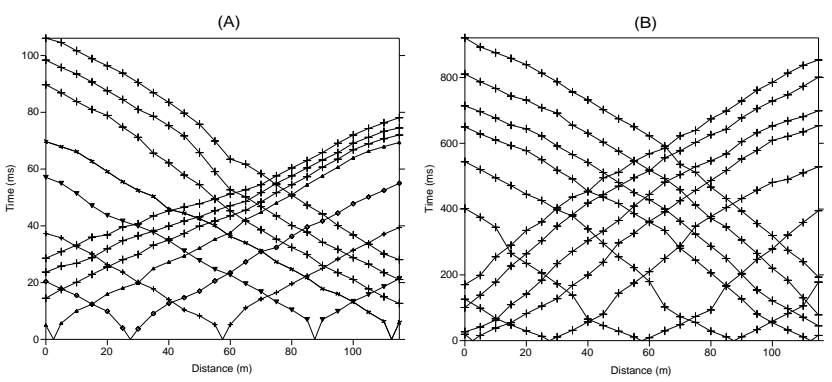

Figure 8 First arrival time vs distance graph for profile line S3; (a) P-wave, and (b) S-wave

Figure 9 - 11 show the 2-D tomography section of the seismic refraction $\mathrm{P}$ - and $\mathrm{S}$-waves for the profile lines of S1 - S3 respectively. Each profile line of the Pand S-waves show a significant tomography in identifying variations of seismic velocity due to lithology and subsurface characteristics (density, moduli), and its very significant to interpret the boundary of interest in the study area.

The seismic refraction P-wave tomography (Figure $9 a, 10 a$ and $11 a$ ) indicate the study area is divided into four layers. The first layer (top layer) with P-wave velocity (Vp) of $<750 \mathrm{~m} / \mathrm{s}$; second layer with depth of
$0-5 \mathrm{~m}$ and velocity ( $\mathrm{Vp}$ ) of $750-1275 \mathrm{~m} / \mathrm{s}$; the third layer with depth of $0-12 \mathrm{~m}$ and velocity (Vp) of 1275 - $1684 \mathrm{~m} / \mathrm{s}$; and the forth layer with depth of $3-55 \mathrm{~m}$ and velocity $(\mathrm{Vp})$ of $>1684 \mathrm{~m} / \mathrm{s}$. The highest value of $\mathrm{Vp}$ layer $(1684 \mathrm{~m} / \mathrm{s})$ is within the related range of compressional velocities for saturated soil and was probably indicative of unconsolidated sediment, and the change in $\mathrm{Vp}$ at this boundary is $1275 \mathrm{~m} / \mathrm{s}$. The variation of the $V p$ is due to bulk modulus and subsurface strength.

The seismic refraction S-wave tomography (Figure $9 \mathrm{~b}, 10 \mathrm{~b}$ and $11 \mathrm{~b}$ ) indicate the study area is also divided into four layers. The first layer (top layer) with $\mathrm{S}$-wave velocity $(\mathrm{Vs})$ of $<121 \mathrm{~m} / \mathrm{s}$; second layer with depth of $0-12 \mathrm{~m}$ and velocity (Vs) of $121-196 \mathrm{~m} / \mathrm{s}$; the third layer with depth of $15-42 \mathrm{~m}$ and velocity (Vs) of $196-265 \mathrm{~m} / \mathrm{s}$; and the forth layer with depth of $25-45 \mathrm{~m}$ and velocity (Vs) of $>265 \mathrm{~m} / \mathrm{s}$. Generally, it was identified that the Vs value is about $15 \%$ of the $\mathrm{Vp}$ value, with relatively small variation of $\mathrm{Vs}$. At a depth of $35 \mathrm{~m}$ where the unconsolidated sediment was found, the $\mathrm{Vp}$ and $\mathrm{Vs}$ values were greater than $1680 \mathrm{~m} / \mathrm{s}$ and $260 \mathrm{~m} / \mathrm{s}$ respectively. Increase in Vs value occurred in the water saturated unconsolidated sediments such as shown in the timedistance graph. This could occur if Vs variations and values was too low in relation to the depth due to shear modulus and Poisson's ratios for the lithological units.
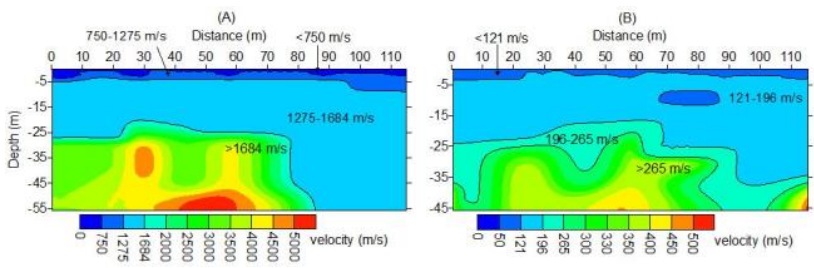

Figure 9 Refraction tomography for spread line S1; (a) Pwave, and (b) S-wave
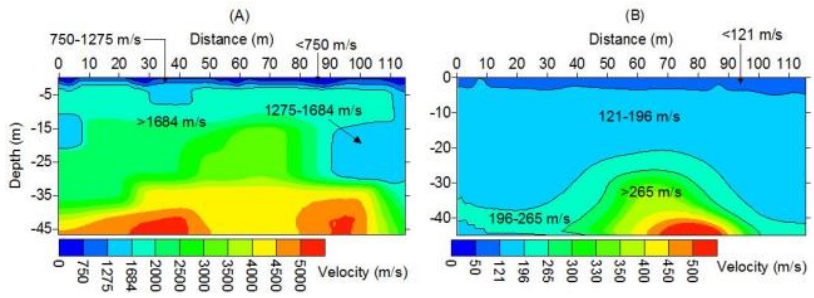

Figure 10 Refraction tomography for spread line S2; (a) Pwave and (b) S-wave
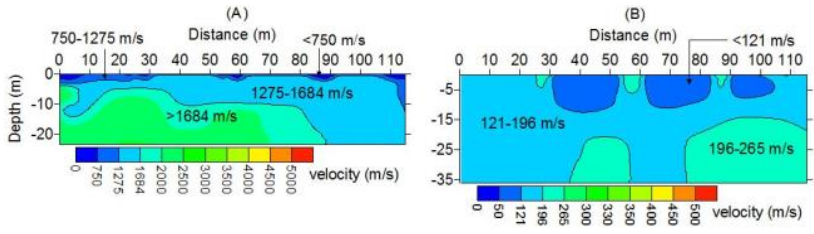

Figure 11 Refraction tomography for spread line S3; (a) Pwave and (b) S-wave 
The Vp and Vs were analysed to identify the relation. The $V p$ and $V s$ for each layer were identified using 2$D$ tomography section of the seismic refraction $\mathrm{P}$ and S-waves were plotted as shown in Figure $12-14$. The relation for each layer shows a high value of coefficient of determination $\left(R^{2}\right)$ between $V p$ and $V s$ with values of $>0.7509$ (strong to very strong relation) except for the first layer of profile line S3 with $\mathrm{R}^{2}$ value of 0.2208 due to subsurface heterogenity in the layer $[44,45]$. The $\mathrm{Vp} / \mathrm{Vs}$ ratio for each layer were also calculated. Table 5 shows the summary of the $\mathrm{R}^{2}$ values and $\mathrm{Vp} / \mathrm{Vs}$ ratio for the three profile lines and related layer respectively.

The results indicate that $\mathrm{Vp} / \mathrm{Vs}$ varies from 4.75 to 5.79 at first layer representing the top soils. Second and third layer with $\mathrm{Vp} / \mathrm{Vs}$ variation of 6.50 to 8.89 and 6.57 to 12.17 respectively, representing the highly saturated sediments. The bottom layer with a $\mathrm{Vp} / \mathrm{Vs}$ range of $6.08-8.21$, exhibit the partially saturated sediments. This $\mathrm{Vp} / \mathrm{Vs}$ variations, laterally and vertically, are interpreted as unconsolidated sediments which are saturated with water [28, 32], and its related to the high degree of heterogenity of the sediments investigated.

The results gained by seismic refraction method is very significant in determination of shallow subsurface characteristics. The compressional to shear waves velocity ratio (Vp/Vs) can indicate variations in lithology and the presence of clay and silt in sediments causes an increase in $\mathrm{Vp} / \mathrm{Vs}$. By increasing the degree of water saturation at the pore spaces, will affect the nature of the sediment, which results in an increase in the velocity ratio, that are characterizing the subsurface deposits, both horizontally and vertically.

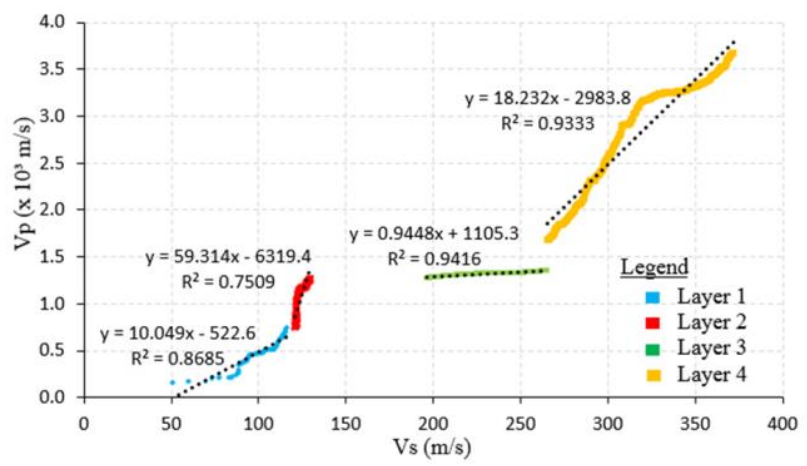

Figure 12 The $V p$ against $V s$ plot for each layer of profile line Sl at study area

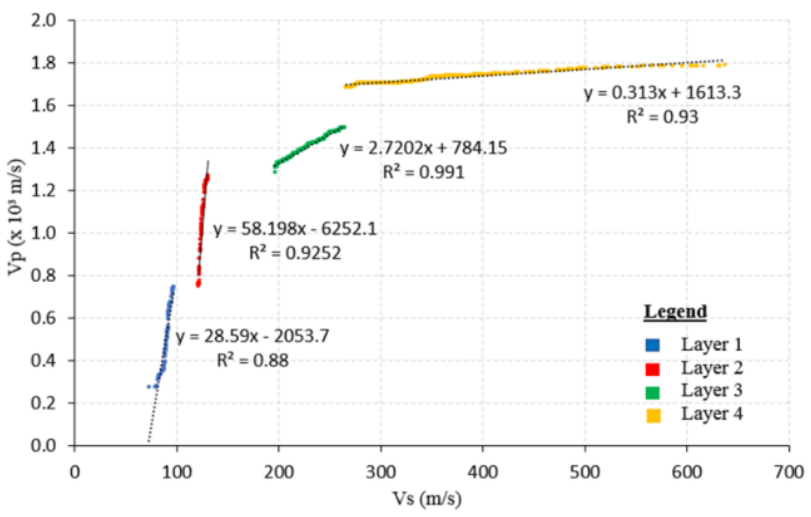

Figure 13 The Vp against Vs plot for each layer of profile line S2 at study area

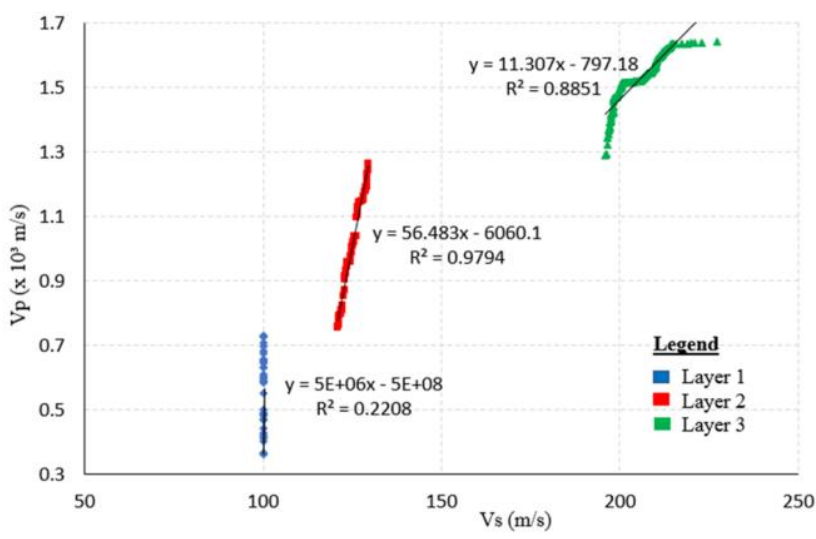

Figure 14 The Vp against Vs plot for each layer of profile line S3 at study area

Table 5 The $\mathrm{R}^{2}$ values for the respective layer of profile lines of the study area

\begin{tabular}{|c|c|c|c|c|c|c|}
\hline $\begin{array}{l}\text { Profile } \\
\text { name }\end{array}$ & $\begin{array}{c}\text { Layer } \\
\text { no. }\end{array}$ & $V_{p}(\mathrm{~m} / \mathrm{s})$ & $V_{s}(\mathrm{~m} / \mathrm{s})$ & \begin{tabular}{c|}
$\mathbf{R}^{2}$ \\
values
\end{tabular} & Empirical relation & $\mathrm{Vp} / \mathrm{Vs}_{\mathrm{s}}$ \\
\hline \multirow[t]{4}{*}{ S1 } & 1 & $<750$ & $<121$ & 0.8685 & $V_{p}=10.049 V_{s}-522.6$ & 4.75 \\
\hline & 2 & $750-1275$ & $121-196$ & 0.7509 & $V_{p}=59.314 V_{s}-6319.4$ & 8.89 \\
\hline & 3 & $1275-1684$ & $196-265$ & 0.9416 & $V_{p}=0.9448 V_{s}+1105.3$ & 6.57 \\
\hline & 4 & $>1684$ & $>265$ & 0.9333 & $V_{p}=18.232 V_{s}-2983.8$ & 8.21 \\
\hline \multirow[t]{4}{*}{ S2 } & 1 & $<750$ & $<121$ & 0.88 & $V_{p}=28.59 V_{s}-2053.7$ & 5.79 \\
\hline & 2 & $750-1275$ & $121-196$ & 0.9252 & $V_{p}=58.198 V_{s}-6252.1$ & 6.78 \\
\hline & 3 & $1275-1684$ & $196-265$ & 0.991 & $V_{p}=2.7202 V_{s}+784.15$ & 6.65 \\
\hline & 4 & $>1684$ & $>265$ & 0.93 & $V_{p}=0.313 V_{s}+1613.3$ & 6.08 \\
\hline \multirow[t]{3}{*}{ S3 } & 1 & $<750$ & $<121$ & 0.2208 & $V_{p}=5 \times 10^{6} V_{s}-5 \times 10^{8}$ & 5.54 \\
\hline & 2 & $750-1275$ & $121-196$ & 0.9794 & $V_{p}=56.483 V_{s}-6060.1$ & 6.50 \\
\hline & 3 & $1275-1684$ & $196-265$ & 0.8851 & $V_{p}=11.307 V_{s}+797.18$ & 12.17 \\
\hline
\end{tabular}

\subsection{CONCLUSION}

The study area is classified into four layers according to the $V p$ and $V s$ values with strong to very strong correlation between the values. The $\mathrm{Vp} / \mathrm{Vs}$ ratio value for the first to forth layer is $4.75-5.79 ; 6.50-$ $8.89 ; 6.57-12.17$ and $6.08-8.21$ respectively. This ratio values indicate that these layers are unconsolidated sediments which are saturated with water [28, 32]. This study concludes that ground subsurface of Banda Aceh district is classified into four layers with total depth up to $55 \mathrm{~m}$ and $\mathrm{Vp} / \mathrm{Vs}$ ratio value is $4.75-12.17$, which indicate as water 
saturated unconsolidated sediments that mixed with clay and silt $[33,34]$.

\section{Acknowledgement}

This research is fully supported by Ministry of Education and Culture Indonesia, by its financial support in the scheme of Decentralized Research Competitive Grants Program 2020 PDUPT. The authors would like to thank the Syiah Kuala University (Indonesia), and Universiti Sains Malaysia (Malaysia). Special thanks are extended to the staffs and geophysics students, School of Physics, Universiti Sains Malaysia and Geophysics Students, Faculty of Sciences and Faculty of Engineering, Syiah Kuala University for their assistance during the data acquisition.

\section{References}

[1] Steeples, D. W., 2000: A review of shallow seismic methods. Annali di Geofisica, Published by Istituto Nazionale di Geofisica e Vulcanologia, Bologna, Italy, 43, 6, 1021-1044.

[2] Steeples, D. W., Miller R. D., 1990: Seismic reflection methods applied to engineering, environmental and groundwater problems. In: Ward S. H., Editor, Geotechnical and engineering geophysics, volume 1: Society of Exploration Geophysicists, $389 \mathrm{p}$.

[3] Haeni, F. P., 1986: Application of seismic refraction methods in groundwater modelling studies in New England. Geophysics, 51, 2, 236-249.

[4] Nazarian, S., Stokoe II K. H., Hudson W. R., 1983: Use of spectral analysis of surface waves method for determination of moduli and thicknesses of pavement systems. Transportation Research Record, 930, 38-45.

[5] Park, C. B., Xia J., Miller R. D., 1998: Groundroll as a tool to image near surface anomaly. 68th Ann. Internal. Mtg, Soc. Expl. Geophys., Expanded Abstracts, 874-877.

[6] Park, C. B., Miller R. D., Xia J., 1999: Multi channel analysis of Surface waves. Geophysics, 64, 800-808.

[7] Xia, J., Miller R. D., Park C. B., 1999: Estimation of near surface shear wave velocity by inversion of Rayleigh waves. Geophysics, 64, 3, 691-700.

[8] Xia, J., Miller R. D, Park C. B., 2000: Advantages of calculating shearwave velocity from surface waves with higher modes. SEG Technical Program Expanded Abstracts 2000, 1295-1298.

[9] Beng, T. S., Seng Y. K., Choo L. W., 1982: A seismic refraction survey for an expressway project in Singapore. Bulletin of the International Association of Engineering Geology - Bulletin de l'Association Internationale de G'eologie de l'Ing'enieur, 26, 1, 321-326.

[10] Cardarelli, E., Cercato M., De Donno G., 2014: Characterization of an earth-filled dam through the combined use of electrical resistivity tomography, $\mathrm{P}$ - and $\mathrm{SH}$-wave seismic tomography and surface wave data. Journal of Applied Geophysics, 106, 87-95

[11] Coulouma, G., Samyn K., Grandjean G., Follain S. Lagacherie P., 2012: Combining seismic and electric methods for predicting bedrock depth along a Mediterranean soil toposequence. Geoderma, Elsevier, 170, 39-47.

[12] McClymont, A., Bauman P., Johnson E., Pankratow L., 2016: Geophysical Applications to Construction Engineering Projects. CSEG Recorder, 41, 4.

[13] Gabr, A., Murad A., Baker H., Bloushi K., Arman H. Mahmoud S., 2012: The use of sesmic refraction and electrical techniques to investigate groundwater Aquifer, Wadi Al-Ain, United Arab Emirates (UAE). Conference Proceedings, 14-16 September 2012, Tulcea-Romania.

[14] Osumeje, J. O., Kudamnya E. A., 2014: Hydro-geophysical Investigation Using Seismic Refraction tomography to Study the Groundwater potential of Ahmadu Bello University main campus, within basement Complex of Northern Nigeria. Journal of environment and Earth Science, 4, 2, 16-22.

[15] Pandula, B., 2000: Determination of degree of breakage and quality of airport ways by seismic methods. Acta Montanistica Slovaca, 5, 2, 157-162.

[16] Shtivelman, V., 2003: Application of shallow seismic methods to engineering, environmental and groundwater investigations. Bolletino di Geofisica Teorica e Applicata. An international journal of Earth Science. Trieste, Italy, 44, 3-4, 209-222.

[17] Prekopov'a, M., Jano cko J., Budinsk'y V., Friedmanov'a M., 2016: Integration of seismic and sedimentological methods for analysis of Quaternary alluvial depositional systems. Environ. Earth Sci. 2017) 76:25, Springer https://doi.org/10.1007/s12665-016-6345-3.

[18] Tsokas, G. N., Papazachos C. B., Vafidis A., Loukoyiannakis M. Z., Vargemezis G., Tzimeas K., 1995: The detection of monumental tombs buried in tumuli by seismic refraction. Geophysics, 60, 6, 1735-1742.

[19] Shahrukh, M. Soupios P., Papadopoulos N., Sarris A., 2012: Geophysical investigations at the Istron archaeological site, eastern Crete, Greece using seismic refraction and electrical resistivity tomography. Journal of Geophysics and Engineering, 9, 6, 749-760.

[20] Salem, H. S., 1993. A preliminary study of the physical properties of the Terra Nova and Hibernia oil fields in the Jeanne d'Arc Basin, offshore Newfoundland, Canada. Geol. Surv. Can., OFR 2686, Dossier Public, Halifax, NS, 79.

[21] Salem, H.S., 2000. The Compressional to shear wave velocity ratio for surface soils and shallow sediments. European Journal of Environmental and Engineering Geophysics, 5, 1, 3-14.

[22] Mavko, G. and Mukerii, T., 1998. Short Note - Comparison of the Kreif and critical porosity models for prediction of porosity and Vp/Vs. Geophysics, 63, 925-927.

[23] Pickett, G. R., 1960. The use of acoustic logs in the evaluation of sandstone reservoirs. Geophysics, 25, 250274.

[24] Pickett, G. R., 1963. Acoustic character logs and their application in formation evaluation. Trans. AIME, 15, 659667.

[25] Benzing, W. M., 1978. Vp/Vs relationships in carbonates and sandstones - Laboratory data. Expanded Abstr., 48th Ann. Internat. SEG Mtg., San Francisco.

[26] Benzing, W. M., Byerly, P. E. and Hopkins, J. R., 1983. Shear and compressional wave data interpretation - Midland Basin, Taxes. Expanded Abstr., 53rd Ann. Internat. SEG Mtg., Las Vegas.

[27] Hamilton, E. L., 1979. Vp/Vs and Poisson's ratio in marine sediments and rocks. J. Acous. Soc. Am., 66, 1093-1101.

[28] Gardner, G. H. F. and Harris, M. H., 1968. Velocity and attenuation of elastic waves in sands. Trans. SPWLA, 9th Ann. Logging Symp., M1-M19.

[29] Gregory, A. R., 1977. Aspects of rock physics from laboratory and log data that are important to seismic interpretation. In: Pyton, C.E. (Ed.) Seismic stratigraphy Applications to hydrocarbon exploration. Bull. AAPG, Mem. 26, Tulsa: 15-64.

[30] Tatham, R. H., 1982. Vp/Vs and lithology. Geophysics, 47, 336-344.

[31] Tatham, R. H., 1985. Shear waves and lithology. In: Dohr, G. (Eds.), Seismic shear waves, Part B. Geophysical Press, London. 87-133.

[32] Eastwood, R. L. and Castagna, J. P., 1983. Basis for interpretation of $\mathrm{Vp} / \mathrm{Vs}$ ratios in complex lithologies. Trans. SPWLA, 24th Ann. Logging Symp., G1-G17. 
[33] Stuempel, H., Kaehler, S., Meissner, R. and Milkereit. B., 1984. The use of seismic shear waves and compressional waves for lithological problems of shallow sediments. Geophy. Prosp., 32, 662-675.

[34] Meissner, R., Stuempel, H. and Theilen, F., 1985. Shear wave studies in shallow sediments. In: Dohr, G. (Ed.), Seismic shear waves - Part B. Geophysical Press, London. 225-253.

[35] Castagna, J. P., Batzle, M. L. and Eastwood, R. L., 1985. Relationship between compressional wave and shear wave velocities in clastic silicate rocks. Geophysics, 50, 571-581.

[36] Bennett, J.D., Bridge, D.McC., Cameron, N.R., Djunuddin, A., Ghazali, S.A., Jeffery, D.H., Kartawa, W., Keats, W. Rock, N.M.S., Thomson, S. J. and Whandoyo, R. (1981a). Geologic Map 1:250,000 of Banda Aceh Quadrangle, Sumatra. Geological Research and Development Centre, Bandung.

[37] Culshaw, M.G., DuncanS.V. and Sutarto N.R., 1979, Engineering Geological Mapping of The Banda Aceh Alluvial Basin, Northern Sumatra, Indonesia, Bulletin of the International Association of Engineering Geology, 19, 4047.

[38] Soetrisno, S. (1993a). Hydrogeological Map 1:250,000 of Indonesia, Sheet 0421 Banda Aceh, Directorate of Environmental Geology, Bandung.
[39] Soetrisno, S. (1993b). Hydrogeological Map 1:250,000 of Indonesia, Sheet 0521 Leikseumave/ Simpangilum, Directorate of Environmental Geology, Bandung.

[40] Setiadi, Hendri (2004). Hydrogeological Map 1:1,000,000 of Indonesia. Directorate of Geological and Mining Area Environment, Bandung.

[41] Google Earth, 2020.

[42] Sabrian, T.A., Saad, R., Saidin, M.M., Muhammad, S.B. and Yusoh, R. (2018). Empirical Approach in Developing Vs/Vp Ratio for Predicting S-Wave Velocity, Study Case; Sungai Batu, Kedah. IOP Conf. Series: Journal of Physics: Conf. $\begin{array}{lllll}\text { Series } & 995 & \text { (2018) } & 012089 & \text { doi }\end{array}$ 6596/995/1/012089

[43] Nadia, R., Saad, R., Muztaza, N., Ismail, N.A. and Saidin, M.M. (2016). Geotechnical Parameters Study Using Seismic Refraction Tomography. Jurnal Teknologi (Sciences \& Engineering). 78: 8-6 (2016) 93-98.

[44] Evans, J. D., 1996. Straightforward statistics for the behavioral sciences (Brooks: Cole).

[45] Zaman, M. W., Hossain, M. R., Shahin, H. M. and Al Alam, M. A., 2016. A study on correlation between consolidation properties of soil with liquid limit, in-situ water content, void ratio and plasticity index. Geotechnics for Sustainable Infrastructure Development - Geotec Hanoi 2016, Phung (edt). ISBN 978-604-82-1821-8. 